\title{
"Educate, Agitate, Organize": Inequality and Ethics in the Writings of Dr. Bhimrao Ramji Ambedkar
}

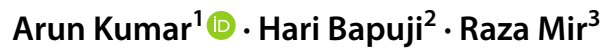

Received: 3 July 2020 / Accepted: 8 February 2021 / Published online: 25 February 2021

(c) The Author(s) 2021

\begin{abstract}
Scholars of business and management studies have recently turned their attention to inequality, a key issue for business ethics given the role of private firms in transmitting-and potentially challenging-inequalities. However, this research is yet to examine inequality from a subaltern perspective. In this paper, we discuss the alleviation of inequalities in organizational and institutional contexts by drawing on the ideas of Dr. B. R. Ambedkar, a jurist, political leader and economist, and one of the unsung social theorists of the twentieth century. Specifically, we focus on Ambedkar's critique of the Indian caste system, his outline of comprehensive reform, and prescription of representational politics to achieve equality. We contend that an Ambedkarite ethical manifesto of persuasion-focussed on state-led institutional reforms driven by the subaltern-can help management researchers reimagine issues of inequality and extend business ethics beyond organizational boundaries.
\end{abstract}

Keywords B. R. Ambedkar · Caste · Ethics · Inequality

The assertion that inequalities around the world have been rising has now achieved the status of an axiomatic reality. In the United States, the top $1 \%$ of the population earns over $20 \%$ of the national income (compared to $11 \%$ in 1980), while the bottom $50 \%$ earns less than $13 \%$ (compared to over $20 \%$ in 1980) (Alvaredo et al. 2017). The worrying trend continues to grow. Recognizing the central role of corporations in the creation and maintenance of inequality, organizational scholarship has devoted considerable research attention to understand the causes and consequences of inequality (Amis et al. 2020; Bapuji et al. 2020a). This research has shown that organizations create inequalities by providing differential value creation opportunities for individuals (e.g.

Arun Kumar

arun.kumar@york.ac.uk

Hari Bapuji

hari.bapuji@unimelb.edu.au

Raza Mir

mirr@wpunj.edu

1 University of York, LMB/226, Freboys Lane, Heslington YO10 5GD, York, UK

2 University of Melbourne, 10, 060, The Spot, Parkville, VIC 3010, Australia

3 William Paterson University, 3062, Valley Road, Wayne, NJ 07470, USA employment, wages and benefits, career advancement, and CSR) based on their demographic characteristics (e.g. gender, race, and class) (Amis et al. 2020; Bapuji et al. 2020b).

Given its debilitating consequences for individuals, organizations, and societies (Bapuji et al. 2020a; Wilkinson and Pickett 2009), rising inequality within organizations and in society represents a fundamental ethical dilemma of our times, which business ethics' scholars have only recently begun to address (see for e.g. Beal and Astakhova 2017; Jagannathan et al. 2020; Rauf and Prasad 2020). In this scholarship, and in management research broadly, demographic characteristics from non-Western contexts (e.g. caste, community) have received limited attention - of which caste is our focus, here (Chrispal et al. 2020). This inattention to non-Western contexts and demographic characteristics is telling given the extensive and long-standing evidence of exclusion of people from lower and untouchable castes from social, educational, and economic institutions rendering them "subaltern". Following the formulation by the Italian theorist Antonio Gramsci and subsequent neo-Gramscian scholars, the "subaltern" are understood as dependent, marginalized, and powerless-subordinated on account of their caste and relatedly occupational and class status in the context we discuss (Gramsci 1971; Guha 1988; Srinivas 2013).

In this paper, we present a subaltern perspective that sheds light on systems of inequality and propounds 
"representational politics" as a way of challenging inequality from below. In order to understand and counter socioeconomic inequalities from below, we discuss the life and works of Dr. Bhimrao Ramji Ambedkar (Ambedkar, henceforth). Ambedkar offers a potential counter to ideological approaches to business ethics that normalize institutional barriers to the fruits of social productivity for the global poor, particularly those living outside the developed countries. Ambedkar's intervention rested on the contention that the Indian caste system denied India's lower castes the opportunity for socioeconomic mobility. The caste system involves a hierarchical division of society, where socioeconomic rights of different caste groups are pre-determined by their birth and heredity alone, not their ability (Akerlof 1976; Ambedkar 1936). Despite constitutional reform, affirmative action, and centuries-long socio-political movements for equality, a stringent caste-based economic system remains in place through social and cultural stigmatization, economic penalties, and physical and verbal violence (Bapuji and Chrispal 2020; Thorat and Newman 2007).

Ambedkar's writings and his philosophy has wider relevance to all oppressed and socially disadvantaged castes and classes, which in India are commonly referred to as DalitBahujan groups. ${ }^{1}$ As part of "representational politics", he theorized a way in which lower castes could mobilize, organize, and demand an equal seat at the table of citizenship. In fact, the title of this article is borrowed from his call to the oppressed to "educate, agitate, and organize", and thereby wage a battle for freedom and reclamation of human personality. We contend that an Ambedkarite approach, adopted more generally, can be used to address the persistent inequalities that beset those workers who are denied access to the surplus value that their labour generates.

We outline three reasons for Ambedkar's contemporary relevance in India and globally. Firstly, Ambedkar's work has considerable relevance for understanding Indian society. Despite the oppressive environment he lived in, Ambedkar

\footnotetext{
1 The term "Dalit" literally means someone who is oppressed or broken. It is used to refer to castes widely considered to be "untouchable" by other caste Hindus as their economic roles are severely restricted to stigmatized occupations. The Dalits are also referred to as Scheduled Castes as these caste groups were listed in the Indian Constitution's (Scheduled Castes) Order, 1950. "Bahujan" is an umbrella term used to refer to vast majority of oppressed and socially disadvantaged castes in the country not limited to those considered untouchable. In addition to Dalits, Bahujan includes Adivasis (tribal peoples) and Shudra (mainly peasant and other castes engaged in manual work) castes. Depending on who they are writing about and for what purposes, different authors use the terms separately and together. Some scholars and activists prefer the term Bahujan to denote both that caste is not just a problem for those severely oppressed but for the wider Hindu society, and to highlight the numerical strength of those oppressed (Ilaiah-Shepherd 2018; Karunakaran 2016; Teltumbde, 2017).
}

consistently articulated a trenchant critique of mainstream Indian society for its role in the perpetuation of inequalities. His name stands out as one of the few who led the battle for sovereignty and the search for the "Indian self" (Vajpeyi 2012). In fact, while the philosophies of other comparable political leaders like Gandhi and Nehru are losing steam in recent times, Ambedkar's thought is increasingly gaining relevance in the social, political, and economic discourse in India. ${ }^{2}$ Secondly, while Ambedkar's writings were specific to India and its caste-based inequalities, the values he espoused are universal in nature. Specifically, by writing against the systems of inequality (e.g. caste, patriarchy) that reduced large populations to subhuman status, Ambedkar propounded the idea that all human beings are equal and deserve a life of dignity and opportunity. Engaging with the ideas of Ambedkar is, therefore, particularly important in the current age where inequalities are giving rise to authoritarian leaders and weakening the ideals of egalitarianism and democracy (Kumar 2015; Sprong et al. 2019). ${ }^{3}$ Thirdly and finally, while extant scholarship on business ethics has been dominated by Western moral philosophers (Heath et al. 2010), we contend that non-Western, subaltern approaches from political philosophy can vastly expand the ethical analysis of inequality as well as other grand challenges faced by organizations and societies (Khare and Varman 2016; Mahalingam 2003; Mahalingam et al. 2019; Varman and Vijay 2018).

In offering Ambedkar's subaltern perspective for challenging inequality, the paper makes the following contributions. First, it draws on Ambedkar's 17-volume Writings and Speeches to elucidate a major ethical challenge of our times, i.e. inequality. In particular, it helps outline how systems of social, cultural, and political inequality underlay and reinforce economic and political inequalities, including their deleterious effects on individuals from subaltern communities. Second, it illustrates the potential of Ambedkar's thought to rethink the institutional and organizational mechanisms to achieve equality for subaltern populations in response to a more complex and comprehensive understanding of inter-linked systems of inequality. Third and most importantly, we hope that our introduction to an overlooked political philosopher and a subaltern perspective to the field of business ethics will be generative-that is, not only will it encourage ethics scholars to focus on institutionalized

\footnotetext{
${ }^{2}$ For example, a Google search for Gandhi, Nehru, and Ambedkar in Google's Ngram tool shows a steep decline in the appearance of Gandhi and Nehru from late 1980s, but mentions of Ambedkar although lower are gradually increasing in the same period.

3 In contemporary India, recent socio-political changes are often critiqued from the perspective of constitutional principles that Ambedkar was an architect of rather than other philosophies, such as Gandhian principles.
} 
and organizational inequalities, but also to initiate scholarly activism that Ambedkar exemplified.

The remainder of this paper is organized as follows. First, we provide a brief biography of Ambedkar to familiarize readers with his life and work, as well as to provide the context of his scholarship. Then, we explain three main areas of Ambedkar's scholarship: (i) a radical critique of caste-based inequalities in Indian society; (ii) his insistence on a comprehensive reform across different institutional realms and organizational spaces; and (iii) his emphasis on the pursuit of justice and equality by deploying representational politics. We conclude by discussing the implications of these three core ideas into building a subaltern, Ambedkarite manifesto to interrogate contemporary inequalities, and implicitly challenge theorists of business ethics to contest formulations of ethical organizational behaviour that have been denatured of their larger socio-political and economic contexts.

\section{B.R. Ambedkar: A Brief Biography}

Popularly known as Babasaheb (translated as revered father), Ambedkar was born on 14 April 1891 in Mhow, a small town in central India. He was born to a Mahar family. The Mahars were one of the largest untouchable castes of India, who traditionally served as village servants for the headman, overlords, and other dominant groups of the village. The caste system is an informal institution that places individuals in fixed positions based on patrilineage on a system of graded hierarchy. The relative position of the individual heavily influences, if not determines, their occupation, social status, as well as social and family life choices. An individual's caste has historically determined the various types of capital-economic, social, cultural, and symbolic - that they inherit and/or are able to access and acquire (Bapuji and Chrispal 2020).

During British colonial rule, the Mahars experienced upward social mobility as they were able to pursue newly available jobs in road and rail construction, mills and factories, and in the Indian armies of the British (Zelliot 1970). Although the caste system traditionally denied education to untouchables, Ambedkar's father Ramji (who served as an officer in the British Army) was committed to his son's educational progress. ${ }^{4}$ In 1913, Ambedkar graduated from Elphinstone College, Bombay (now Mumbai) with a BA in English and Persian. Later that year, he departed for New

\footnotetext{
4 The transformations within the Mahar community influenced Ambedkar as he grew up in a family that was free from the traditional roles and placed its aspiration in modernity: education, employment, administration, etc. In turn, Ambedkar influenced the Mahar movement and transformed it such that they were no longer merely aspiring for an incremental improvement in social status, but were aiming for the top (Zelliot 1969).
}

York for his higher studies on a scholarship sponsored by a local prince from Baroda (in present day Gujarat).

Enrolled at Columbia University, Ambedkar studied various social sciences under leading lights such as John Dewey who later became an important influence on Ambedkar's views on democracy and its place and significance in twentieth-century India (Mukherjee 2009). While at Columbia, Ambedkar wrote an essay interrogating the caste system in India titled 'Castes in India: Their mechanism, genesis, and development' (Ambedkar 1916), which contested most of the theories of caste then prevalent, including those based on religion and purity, occupations, and Indological formulations of tradition (Teltumbde 2017). Instead, he theorized that caste originated as a class system, but was distinguishable by its emphasis on endogamy, which worked to ensure that the system remained rigid and impenetrable. Endogamy, Ambedkar (1916 [AWS01: 18]) noted, resulted in gross inequalities and denial of opportunities for mobility as "Some closed the door: Others found it closed against them".

Ambedkar went on to earn two doctorates in economics: first from Columbia University and later at the London School of Economics. While in London, Ambedkar also completed his legal training and was called to the bar at Gray's Inn. In 1924, he returned to Bombay. Despite his extensive education from some of the world's leading institutions, Ambedkar continued to encounter caste-based discrimination and inequalities (Ambedkar 1990 [AWS12]). For example, in 1924 following his return to India, he found it difficult to establish his own legal practice, as caste Hindus refused to engage his legal services. ${ }^{5}$ Such experiences led Ambedkar to establish the Bahishkrit Hitkarini Sabha (Assembly for the Welfare of the Excluded Peoples) with a motto to "Educate, Agitate, Organize" (on which more later). It paved the way to Ambedkar's emergence as a mass organizer for social, economic, and political reform.

In 1926, he was appointed to Bombay's Legislative Council, where he actively challenged both the colonial government and the Indian nationalists for their regressive and oppressive economic, social, and political practices and for not doing enough for the subaltern masses in the country. His intervention in the emergent movement for Indian nationalist self-determination included a call for provincial autonomy, adult suffrage, and an overhaul of contemporary system of representation. Demanding adult suffrage, Ambedkar noted in his submission: "For to keep people illiterate and then to deny them franchise which is the only means

\footnotetext{
5 Ambedkar encountered numerous such incidents in his life, which resulted in his extensive focus on the caste system as a peculiar system of inequality-distinctive from the class system which depended on education and income. In his unfinished autobiography, he narrated multiple incidents in which he was denied services even when he had the money to pay for them.
} 
whereby they could effectively provide for the removal of their illiteracy is to perpetuate their illiteracy and postpone indefinitely the day of their enfranchisement" (Ambedkar 1928 [AWS02: 340]; emphasis added).

Turning his attention to organizing a Dalit Movement in the country, Ambedkar launched the Mahad Satyagraha (literally, satyagraha means asserting truth) in 1927. Despite a confirmation from Mahad's city council that its Chavadar lake was open to use for members from the supposedly untouchable castes, the city's upper-caste Hindus continued to deny the latter access to the lake. Leading the agitation, Ambedkar exhorted his followers: "It is high time that we rooted out from our mind the ideas of highness and lowliness among ourselves" (Samel 1999, p. 724). He then proceeded to drink water from the lake, and thousands of his followers followed suit. Subsequently, the upper-caste Hindus opposed his actions and 'purified' the lake, prompting Ambedkar to launch a second agitation and declare: "We are resorting to this Satyagraha not because we believe that the water of this particular tank has any exceptional qualities, but to establish our natural rights as citizens and human beings" (Ibid., 726). At this second agitation in December 1927, Ambedkar symbolically burnt a copy of the Hindu religious text Manusmriti (which codifies caste, gender, and economic inequalities, see Ali 2020) denouncing it as "the Bible of slavery to the Shudras, the Hindu women and untouchables" (Ibid., 726). Ambedkar called for a new code that provided "freedom and equal rights to those who were deprived of human respect and dignity;" which rapidly grew into a wider, national-level movement for ending caste and gender-based inequalities (Samel 1999, p. 726).

To reform the system of political representation, Ambedkar called for the abolishment of all class-based electorates (such as electorates of landholders, traders, industrialists, etc. whether they were Indians or Europeans) and communally separate electorates (for Muslims, Europeans, Anglo-Indians, etc.) in 1928. He was of the opinion that the interests of specific communities or classes were best served through general electorates by making provisions for reservation of seats, such as for the Dalits (Ambedkar 1928; AWS 02).

During this period, Indian National Congress tended to de-emphasize the question of the welfare of the nation's subaltern Dalit population, presenting it as secondary to anti-colonial political movement and/or an internal matter. Disillusioned with their approach, Ambedkar raised the demand for separate electorates for the Depressed Classes, a contemporary political term for Dalits. Ambedkar's demand remained unmet as part of his agreement with Gandhi in 1932, which has since come to be known as the Poona Pact. Representing caste Hindus, Gandhi opposed separate electorates as he viewed it as a division and, therefore, weakening of caste-Hindu society. On the other hand, Ambedkar (representing the depressed classes) viewed separate electorates as a possible means of ensuring political power and representation of the Dalits. The then-colonial government accepted Ambedkar's proposal, and Gandhi commenced a "fast unto death" in opposition. As part of the Poona Pact, Gandhi abandoned his fast, and the demand for separate electoral rolls for the Depressed Classes was withdrawn. Instead, the pact provided for quotas in legislative seats for the untouchable classes (Metcalf and Metcalf 2006).

Increasingly disillusioned with the resistance of the political leadership of caste Hindus, Ambedkar plunged more fully into active politics. In 1936, he founded the Independent Labour Party (ILP), declaring it to be the predominant working-class party in the country. It went on to become the largest opposition party in the Bombay legislature. Despite its commitment to workers, ILP's formation was not welcomed by the Indian socialists. The resistance from the leftwing parties in the country led Ambedkar to conclude that caste was not about the "division of labour" as some caste Hindus propounded, but an entrenched system of "division of labourers" (Ambedkar 2014, p. 233).

Continuing his work to build an intersectional alliance of subaltern masses, in 1938 Ambedkar called a Depressed Classes Workers' Conference, where he contended that Brahminism $^{6}$ and capitalism were the two major enemies of the working classes in the country. During this time, Ambedkar continued his challenge of contemporary dominant political regimes. These included the caste-Hindudominated Indian nationalist movement and its various factions, the British colonial government, and the Indian anti-imperialist communists. None of the nationalist interest groups, Ambedkar concluded, displayed any significant and persistent seriousness about the specific and inter-linked oppression encountered by the lower castes (Omvedt 2008).

Frustrated by the lack of expected support from socialists, Ambedkar decided to dissolve the Independent Labour Party and formed the Scheduled Caste Federation (SCF) in 1942, as a national-level party of the untouchables. Earlier that year, Ambedkar was appointed as the Labour Minister to the Viceroy's new Indian cabinet. In addition to labour, Ambedkar also held additional portfolios of irrigation, power, and public works. These provided him with a fuller scope to develop his views and policies

\footnotetext{
${ }^{6}$ Ambedkar used the word Brahminism (and its variant Brahmanism) to distinguish a more rigid and unequal social system that emerged following the struggle for supremacy between Hinduism and Buddhism. Among the things that he suggested characterized Brahminism are (i) infallibility of Vedas or early religious texts, (ii) achievement of salvation only by Vedic sacrifices and ceremonies conducted by Brahmins, (iii) organization of society into groups in a caste system of graded inequality, and (iv) belief that Karma-or the deeds of the past life-determine one's position in this life.
} 
on industrialization, economic planning, and modernization of a soon to be independent India (Thorat 1998).

Continuing to write prolifically and remaining actively involved with SCF, in 1945 Ambedkar wrote What Congress and Gandhi Have Done to the Untouchables, pulling together his extensive, and decades' long criticism of Gandhian reform and Indian Congress's soft, often insincere policies to address caste-based inequalities in the country. His alternative proposal for the economic organization of independent India was presented in his tract titled States and Minorities (1945a). Therein, Ambedkar articulated a system of 'state socialism,' favouring nationalization, planning, and collectivization for rapid economic development. He also developed a social manifesto that guaranteed human rights and rejected untouchability and other related practices.

In July 1947, Ambedkar was appointed as a member of India's Constituent Assembly. Following the independence of India on 15 August 1947, he was appointed as the Law Minister in post-colonial India's first cabinet. Shortly after, he was appointed as a member, and later became the chair, of the drafting committee of the Constituent Assembly tasked with preparing the Indian constitution. He is widely credited as the "chief architect" of the Indian constitution (Brecher 1959). Ambedkar was awarded an honorary doctorate in law from Columbia University in 1952.

In 1956, disillusioned by the reluctance of Hindu leaders to address caste-based inequalities, Ambedkar converted to Buddhism in the city of Nagpur in front of a crowd of over 400,000 of his followers. This was an expressly ideological act, claiming that if the dominant religion in India left no space for the lower castes to enact their social mobility, then abjuring it was the only way forward for the oppressed. Following his own diksha (initiation) into Buddhism, Ambedkar converted his followers and administered an additional twenty-one vows to them, renouncing all aspects of Brahminical Hinduism (Omvedt 2008). They dedicated themselves to a new life, taking refuge in the Buddha from the hierarchies and atrocities they had experienced under the caste system. "It was the climax of a career of studying, political action and all-around leadership of one of the most oppressed populations of the world, the untouchables of India" (Omvedt 2008, p. 155). He died shortly after, found slumped over the papers he had been working on late into the previous night.

Ambedkar has only now begun to get his due as a champion of social justice. In 1990, he was posthumously awarded the Bharat Ratna, India's highest civilian honour. Ambedkar was the first and the only recipient of the award from an untouchable caste.

\section{Battling Inequality: Ambedkar's Writings and Activism}

Although Ambedkar wrote on topics ranging from economics to politics to law, his main focus remained on gaining equality for the oppressed classes, particularly Dalits, or those considered as untouchables: outside or below the Hindu caste order. Dalits have been historically excluded for over two millennia from the public realm: be it economics, politics, religion, society, or culture. Although estimates vary depending on who are counted and how, Dalits constitute between sixteen and twenty five percent of India's total population. Dalits are not restricted to India alone. They can be found in various parts of South Asia and among the diaspora living around the world, including in Australia, Canada, UK, and the United States of America. If they lived in a country of their own, they would constitute the third most populous country in the world, behind only China and India (Teltumbde 2017).

Frequently engaged in menial, stigmatized, and dangerous work, Dalits are often forced into caste-based labour with severely restricted opportunities for any social or economic mobility (Mahalingam et al. 2019). They encounter virulent inequality, exclusion, and discrimination when it comes to education (in particular, higher education), employment and livelihoods, housing, political and cultural participation, and religious worship in South Asia and beyond. Often forced into physical segregation, they live in separate localities in villages, towns, and cities, with severely restricted access to community infrastructure and services: such as those relating to drinking water, schools, subsidized meals, pastoral and agricultural lands, and temples (Bapuji and Chrispal 2020; Chrispal et al. 2020). Despite the Indian Constitution outlawing untouchability, Dalits continue to be subjected to it. In the twentieth century, Ambedkar emerged as a leading and influential voice championing the cause of the Dalits in the country.

From his long and extensive fight against inequality (including his Writings and Speeches), we focus on three main points. First, we analyse Ambedkar's radical critique of caste as a system of inequality. Second, we discuss Ambedkar's repetitive pointing to the need for integrative reform that synthesized a comprehensive programme of social, economic, political, legal, and administrative reform as the only possible means to ensuring justice and equality for the subalterns. Third, we discuss Ambedkar's emphasis on representational politics as the only true means of securing universal human rights.

\section{A Radical Critique of Caste as a System of Inequality}

The early twentieth century witnessed a growing movement aimed at reforming caste-Hindu society. Such movements, including those sponsored by Gandhi, were often supported financially, managed, and even some cases led by capitalists 
such as Ghanshyam Das Birla, Jamnalal Bajaj, and Purshottamdas Thakurdas from Bombay and Calcutta, which were the major commercial centres of twentieth-century India (Kudaisya 2006; Nanda 1990). By and large, such movements were very restrictive. While focussing on reforming specific taboos, rituals, and practices around birth, marriage, widowhood, and death, they tended to leave the casteHindu formulations of family, community, and society intact (Kumar forthcoming). Such moves, Ambedkar argued in his influential Annihilation of Caste (1944, [AWS01]), were inadequate for emancipation as they tended to draw from and rely on scriptural and religious discourses of sin, repentance, evil, etc., which were the root cause of the oppression encountered by the Dalits and other lower castes in the first place.

Drawing on Durkheim's formulation of division of labour, caste-Ambedkar (2014, p. 233) argued—was more a "division of labourers". For example, Dalits were excluded from working as weavers in Bombay textile mills. Arguing that the yarn which needed to be occasionally "sucked on to the shuttle from bobbins" would cause pollution, casteHindu workers objected to the employment of Dalits (Chandavarkar 1994, p. 326; Morris 1960). Even as firms moved to self-threading shuttles or established separate weaving sheds where only Dalit workers were employed, caste-Hindu workers resisted working with them. Such moves to exclude Dalit workers might also be driven by economic considerations as weavers earn higher wages than those employed in other sections of the mills, such as spinning (Morris 1965). Thus, caste functioned not only in dividing the workers into specific occupational categories, but also trapped them into a graded system of hierarchy and inequality that precluded unity among workers. Such division of labourers is also seen in other democratic contexts, such as workers cooperatives and trade unions in which the jobs and roles are allocated according to castes, and internalized caste identities limited social and work interactions to caste peers, thus endangering worker unity (Pandey and Varkkey 2020; Varman and Chakrabarti 2004).

Extending the notion of division of labourers to societal fractions, Ambedkar made a "social efficiency" argument, and noted that caste impeded progress and development. In his words, "You cannot build anything on the foundations of caste. You cannot build up a nation, you cannot build up a morality. Anything that you will build on the foundations of caste will crack and will never be a whole" (Ambedkar 2014, pp. 283-284). Specifically, he argued that the caste system compromised merit and impeded a society's progress. He wrote (Ambedkar, nd; AWS03: 290):

From the secular point of view ... Caste [introduced] a most pernicious mentality among the Hindus. It is to disregard merit and have regard only to birth.... One who is of high birth will be superior to the one who is of low birth although the latter may be superior to the former in point of worth. Under Brahmanism it is birth that always wins, whether it is against birth or against worth. Merit by itself can win no meads (sic). This is entirely due to the dissociation of merits from status which is the work of Brahmanism. Nothing could be better calculated to produce an unprogressive society which sacrifices the rights of intelligence on the altar of aristocratic privilege.

Following his insight about the endogamous nature of caste system, Ambedkar (1916; AWS01) suggested building a programme of "social endosmosis". Dissatisfied with the restricted and largely horizontal mobility provided by caste-Hindu reform movements, Ambedkar envisioned an ideal society that was mobile: full of channels that conveyed changes, it provided varied and free points of contact to its members, and contained different modes of association (Ambedkar 2014, p. 260). Further, he noted (Ambedkar 1945b; AWS 09: 481-2) the inherent violence in societies that lacked endosmosis:

In other countries where the governing class is not a close preserve, where there is social endosmosis between it and the rest, there is a mental assimilation and accommodation which makes the governing class less antagonistic in its composition and less antagonistic to the servile classes in its social philosophy. In other words, the governing class in countries outside India is not anti-social. It is only non-social. In India where the governing class is a close corporation, tradition, social philosophy and social outlook which are antagonistic to the servile classes remain unbroken in their depth and their tenor and the distinction between masters and slaves, between the privileged and the unprivileged continues for ever hard in substance and fast in colour. In other words, the governing class in India is not merely non-social. It is positively antisocial.

Ambedkar made concerted efforts to link his radical critique of Hinduism with the political and economic rationale of the Indian national movement. The Indian freedom movement had been based on a two-point narrative logic. First, it argued that colonialism was a regressive institution that prevented the development of Indian economy and its peoples. Second, it viewed the twinning of development and nationalism as a desirable force (Chatterjee 1993). Ambedkar extended the nationalist critique of colonialism by pointing to India's pre-existing, exploitative, social order and its role in the poverty of the Dalit subaltern masses. It was not enough to say, he argued, that there were poor and landless people in the country, but "the poverty of the Depressed 
Classes is due largely to the social prejudices in consequence of which many an occupation for earning a living is closed to them" (Ambedkar 1945b [AWS09: 49]).

Translating his radical critique into a social reform agenda via the modern logic of development, he argued that unless the social order was changed completely, "you can achieve little by way of progress (...) You cannot build up a nation, you cannot build up a morality" (Ambedkar 2014, pp. 283-284). Therefore, the upliftment and "equalization" needed to be at the forefront of any and all governments' efforts (Ambedkar 1945b [AWS09: 49]).

In short, Ambedkar argued that societal inequalities impede individual growth as well as societal development. By shining light on the particularities of the caste system and its differential endowment of rights and privileges on individuals, and their perpetuation through the governance of socioeconomic interactions, he underscored the many interconnected ways in which inequality manifests and endures in a society. Accordingly, he argued for reforms that would target the domains of politics, education, economy, and society in general via granting of reliefs and rights to the underprivileged.

\section{A Comprehensive Reform Programme for Equality}

Ambedkar was distinctive from other leaders of India's national movement, who tended to separate caste into its own, internally administered social realm, distinct from the political struggle for Indian independence. He persistently made a case for Dalits' individual rights and dignity as an integral part of both India's development and its political struggle for independence. Without these indivisible rights, he argued, Indian nationalist movement's outcomes were not particularly relevant (Mukherjee 2009).

Ambedkar's formulation of inter-linked and comprehensive reforms for addressing the inequalities confronting Dalits is best illustrated by the memorandum he submitted to India's Governor-General in 1942. In Grievances of the Scheduled Castes, he discussed Dalits' political, educational, and other grievances separately (Ambedkar 1942 [AWS10]). He further delineated their political grievances into Dalits' inadequate representation in the central legislature and central executive, and complete lack of representation in India's central public services and the Federal Public Services Commission.

In educational grievances, Ambedkar noted that while there were more opportunities for Dalits in the Humanities and Law, there were no opportunities in Science and Engineering. The latter, he argued, were important from an economic perspective as they offered more remunerative opportunities with greater scope for career progression. Interestingly, discrimination based on caste is less pronounced in the 'hard sciences' (Banerjee et al. 2009).
Finally, building on the urgent need for creating opportunities for economic advancement of Dalits, Ambedkar noted the unlikelihood of awarding public contracts to Dalits. Such a denial of opportunities to earn and accumulate not just financial wealth, but also social and reputational capital further disadvantaged Dalits.

Elsewhere, addressing the Railways' Depressed Class Workmen's Conference at Manmad in 1938, Ambedkar noted that the evils suffered by the Dalits originated from the political power usurped by those who later went on to exercise social and economic dominance. Regaining political power, therefore, was a crucial starting point for their agitation against removal of social injustices and for taking up their economic grievances (Keer 1990). Moving past Gandhi's religion-inflected exhortations for partial reform or reform of particular aspects (e.g. untouchability), Ambedkar (2014) set out a comprehensive reform programme that synthesized reforms in different realms, and drew on a wholly modern logic of India's development and progress.

In 1938, for example, he argued that even though the Dalits had been somewhat successful in gaining political power, it was not enough. They needed to seek economic reform to emancipate themselves from the oppression of caste-based, hereditary occupations. Elsewhere in Annihilation of Caste, he drew on social efficiency to point to the constraints posed by hereditary occupations and called for ending them altogether. Such an economic reform, he argued, needed to be necessarily supplemented with wider social and religious reform that would ensure power and authority to Dalits and other lower caste individuals (Ambedkar 2014, p. 227).

In short, Ambedkar suggested that equality cannot be achieved by focusing on one dimension of inequality in a piecemeal fashion, but by pursuing a comprehensive reform that targeted the multiple dimensions of inequality that feed into and reinforce each other. To achieve this, he offered proportional representation for the oppressed as a mechanism to achieve equality and also guard against further entrenchment of inequalities. That matter is what we discuss below.

\section{Representational Politics}

Posing the question about who could raise the Dalits from the "distress in which they are now grovelling", Ambedkar (1942 [AWS10: 441]) wrote:

Their resources are too scanty to afford them the means to raise themselves. They cannot depend upon the charity of the Hindus [which] is beyond question communal in its scope and its benefits are confined to those who belong to the community of the donor (...) The Scheduled Castes have neither of these sources available to them and they are rigorously excluded from the charity founded by both. It was, therefore, 
the duty of the central government to 'rescue' those in distress.

Given the inter-linked nature of inequality encountered by the Dalits, Ambedkar led the agitation for representation of Dalits variously in legislature, administration, public sector banking and industry, etc. The case of Indian civil administration and services is particularly instructive. In 1925, the colonial British government adopted a policy of communal representation to counter the monopoly of "Hindu Brahmins" in the Indian civil services. In 1934, the policy was amended to extend similar provisions to Muslims, AngloIndians, Indian Christians, Sikhs, and Parsis. However, there was no policy in place for Dalits, or what were commonly known as Depressed Classes, then. The amended policy noted that.

No useful purpose will be served by reserving for them (Depressed Classes) a definite percentage of vacancies out of the number available for Hindus as a whole, but they hope to ensure that duly qualified candidates from the Depressed Classes are not deprived of fair opportunities of appointment (cited from Ambedkar 1942 [AWS10: 415])

The policy, though, left open the opportunity for the nomination of Dalit candidates to the civil services. This was not useful as the appointing officers were likely to be Europeans, Hindus, or Muslims, who were-Ambedkar argued - uninformed about the status and conditions of the Dalits, committed to strengthening their own community's interests, and severely prejudiced, respectively (also see Subramanian 2019 for an up-to-date discussion on merit and caste debates in India).

The fallibility of a policy for the underprivileged administered by the privileged was obvious to Ambedkar who saw it from a subaltern perspective. Recent research substantiates his views: it shows that societal inequalities are reproduced in organizations via the logics of meritocracy and efficiency, biases in selection (e.g. homophily), assessments based on culture-fit, and practices of references that advantage the privileged and disadvantage the underprivileged (Amis et al. 2020). Further, organization practices related to work design and compensation management, and even the CSR programmes of companies, normalize and reinforce inequalities in the society when they are designed and administered by managers with demographic privilege (Bapuji et al. 2020b).

Ambedkar concluded that a system of affirmative actionstyle reservations (quotas) was the only means available to the marginalized to ensure the representation of their grievances, legislation for it as a matter of priority, and for its timely and fair implementation. The public services, for example, are often the only available means of employment for Dalits and other lower caste individuals as opportunities in the private sector were severely restricted. Representation in public services served a second crucial function in bestowing government patronage on Dalits, which Ambedkar (1942 [AWS10]) believed was a way of encouraging the spread of primary and higher education in the community. In order to safeguard their representation in politics, Ambedkar (1946 [AWS17.1: 353]) argued that it was important to institute separate electorates to guarantee the election of Dalit candidates in legislatures.

Ambedkar outlined his commitment to representational politics most clearly in SCF's election manifesto from 1951. Committing itself to a policy of industrialization and agricultural development, SCF strove for reservation in higher education (which it deemed particularly important for the pursuit of equality for Dalits) and administration, which he argued had become the monopoly of a handful of communities (Ambedkar 1951 [AWS17.1]).

The representational mechanism (i.e. quotas to ensure adequate representation of disadvantaged minorities) envisaged by Ambedkar is different from the diversity initiatives developed in the West, specifically such as affirmative action. The latter depends on indirect and immeasurable means to achieve equality, whereas Ambedkar's plan was more direct and measurable, and thus achievements can be monitored and evaluated. He felt that in the absence of institutionalized mechanisms for treating representation as a right, institutional representation of Dalits had to be increased by legal fiat.

The need for such institutionalized representational mechanisms is evident in contemporary Indian corporations. Several private sector institutions and corporations have resisted the adoption of quotas, based on the logic of meritocracy. Consequently, top positions and elite professions are still predominantly occupied by the upper castes, even though they constitute a small minority of the country's total population. For example, despite a vast research showing the benefits of diversity to organizations, Brahmins and Vysyas (whose traditional occupation is trading and commerce) together constitute $5 \%$ of Indian population occupy over $90 \%$ of board positions (Ajit et al. 2012). And, lower castes who comprise over $70 \%$ of the population are found in a mere $3 \%$ of academic positions in Indian business schools (Joshi and Malghan 2017). The low presence of the marginalized or slow progress towards equality goes to show why a clear and unwavering implementation of state-mandated representational mechanism is a necessary tool.

In short, a reading of Ambedkar reveals that inequalities are multidimensional and have deleterious effects on the progress and well-being of individuals, organizations, and societies. Therefore, it is necessary to pursue a comprehensive set of reforms that would help the disadvantaged to gain equality in every sphere of life. And, to achieve equality for the marginalized, the mechanisms of representation 
and reservations offer positions as a matter of right to the historically disadvantaged. Such quotas challenge the myths of efficiency and meritocracy as well as the normalization and reinforcement of societal inequalities.

To summarize, we have outlined three main ideas of an Ambedkarite ethical manifesto. These include his radical critique of caste as a social system that produces and perpetuates inter-linked, mutually reinforcing inequalities; his outline of a comprehensive system of reform to achieve equality, covering all organizational realms and institutional spaces; and his demands for representational politics as the possible route towards equality.

\section{Discussion: Towards an Ambedkarite Ethical Manifesto}

Why is Ambedkar's subaltern perspective important and why does it deserve our attention as scholars interested in ethical issues? In this section, we outline two main reasons why Ambedkar's subaltern perspective is necessary to counter socioeconomic inequalities. Firstly, given the systemic nature of inequalities and their reproduction in organizations, state-mandated representation for the disadvantaged is desirable over diversity-led initiatives from the private sector. Secondly, drawing on the work of Gayatri Chakravorty Spivak (1988) we argue that the recognition of oppressed groups as a distinct category of the subaltern is essential to achieve equality in societies where socioeconomic lives were organized based on identity.

Although his position often alienated contemporary elites, Ambedkar was steadfast in his suspicion of conventional social reform in challenging inequalities encountered by the oppressed castes. This stemmed from his prescient understanding of the peculiar relationship between caste and religion. Social reform, he argued, was of three main types: secular reform which had nothing to do with religion; social reform which was aligned with religious principles; and radical social reform that moved counter to religious doctrines, scriptural instructions, and principles. Caste belonged to the third category, whose social reform required disavowal of religion that sanctified it (Ambedkar 2014), as Ambedkar himself did when he and his followers renounced Hinduism.

Building on his views on reforming caste, Ambedkar was emphatic that upper-caste, upper-class elites could not be entrusted with social reform to counter inequalities. His arguments can become the building block of a critique of self-regulation by the capitalist class in present times. Private corporations, philanthropists, civil-society organizations, and religious orders, etc. are increasingly being called to play their role in fighting off inequality on behalf of the marginalized (Di Lorenzo and Scarlata 2019; Gautlier and Pache 2015). But, Ambedkar was clear—at various points in his Writings and Speeches - that governments alone had the mandate and responsibility to support the subaltern in their struggles against inequalities. For example, he argued that businesses and business-leaders were driven by narrow individual and community interests and, therefore, were unwilling to support the subaltern communities (AWS 10: 440-2). Through representational politics—-variously through reservations in governments, police, armed forces, administration, and education, higher salaries, preferential treatment in public contracts, legislations, etc.- - states alone could improve the material circumstances of the historically marginalized groups and make opportunities available to them.

Addressing caste-based inequalities is as relevant today as it was in Ambedkar's time. Debunking globalization's homogenizing myth, Noronha and Sharma (2002) found that job-clustering along ethnic and caste lines has remained an important feature of contemporary Indian industry. As dominant groups cornered well-paying jobs with better working conditions, 'dirty', increasingly casual jobs in the informal sector were left to Dalit migrant workers. Ambedkar's representational politics have contemporary global relevance, as organizations develop diversity and inclusion programmes to improve the presence of demographically disadvantaged groups (e.g. women, ethnic minorities). For example, businesses in India have embraced diversity initiatives aimed at reducing gender inequalities, such as representation on boards, but resisted other types of diversity (such as those in relation to caste, religion, and sexuality). ${ }^{7}$ Even MNEs that operate in India that implement affirmative actions in the West focus only on gender representation, ignoring caste, cultural, linguistic, and regional inequalities (Haq 2012). As a result, even Indian companies increasingly focus on gender and ignore other inequalities, despite the noted losses of lack of caste, class, and religious diversity and recognized benefits of diversity (Haq et al. 2020). These have deleterious outcomes for society as well as individual firms. For example, lack of caste diversity in corporate boardrooms is associated with lower firm value (Dayanandan et al. 2019). Caste, Thorat and Newman (2007) concluded elsewhere, produced considerable economic inefficiencies-in the allocation of labour and resources and impeding the full

\footnotetext{
7 Although scholarly attention to this phenomenon is wanting, we speculate that this is because gender is a visible attribute and thus lack of representation is noticed. In contrast, caste is an invisible attribute and lack of diversity can remain unnoticed. Further, gender diversity does not upset the deep-rooted structures of inequality like other forms of diversity, say caste diversity does. Specifically, diversity initiatives can give preference to women from the upper castes who are socialized into the socioeconomic relations that are shaped by caste. In contrast, individuals from lower castes or religious minorities are not socialized by caste to the same degree and pose a different threat.
} 
development of human capital-and, therefore, constituted a significant financial burden on businesses and societies.

Championed by Ambedkar, representation is a mechanism through which organizations can mitigate against socioeconomic inequalities within the wider society. However, it is far from enough. Even when marginalized individuals are employed, they face discrimination at work, in terms of bullying, assignment of undesirable jobs, lower pay, and slower career progression (Bapuji et al. 2020b; Jagannathan et al. 2020; Noronha 2019). These can occur, particularly in the context of caste because individuals from privileged castes who occupy managerial and executive positions have unfavourable attitudes towards affirmative actions and view the beneficiaries of diversity as less competent (Combs and Nadkarni 2005; Prasad et al. 2020). Such attitudes can be changed by following Ambedkar's call to educate, agitate, and organize.

We now turn to our second key point of representational politics, and its significance for a subaltern ethical manifesto for countering inequality. In a 1988 article provocatively titled Can the Subaltern Speak?, Gayatri Chakravorty Spivak noted that the subaltern-in our case, the marginalized castes reeling under the multiple burdens of caste, capitalism, colonialism, and post-colonial nation-building — cannot speak within the discursive frames of the dominant group (Spivak 1988). These frames are designed to silence them and replace their experience and subjectivity with that of the universal Subject, in this case the dominant class of the corporatized elite. One of Spivak's important contributions is the idea of "strategic essentialism". Spivak begins from the premise that essentialism-reducing diverse and unequal realities to some "essential" truth-is dangerous from the point of view of progressive, liberatory politics. However, too much attention to difference can undermine the building of an effective political movement on behalf of a group. The posing of an essential identity (such as "the poor") as part of a political strategy of opposition/resistance to the status quo can thus serve a useful and necessary (but always limited) purpose. As articulated originally by Spivak, "strategic essentialism" thus referred to a discursive political strategy employed by the subaltern group itself, a strategy that was always to be understood as limited in scope given the dangers inherent in essentialism.

A related concept was the idea of "decolonising the mind" developed by Ngũgĩ wa Thiong'o (Wa Thiong'o 1992). Wa Thiong'o concludes in his magisterial set of essays that it is not enough to change the way a society is ruled: true emancipation can only happen when the institutional "grammar" that underlies colonialism is removed, and replaced by something more equitable. Ambedkar's disillusionment with the mainstream Indian freedom movement stemmed from his realization that for the Dalits and other lower castes, removal of a visible form of exploitation (colonialism) would not remove the invisible form (caste oppression), but might even strengthen it. His insistence on a more comprehensive approach to reform stems from a desire to use the moment of change for a more comprehensive emancipation.

Like Spivak and Thiong'o, Ambedkar began by identifying and naming the very institutional structures that oppressed the subaltern masses in the first place. The conceptual vocabulary and discourse of the dominant, he argued, was never amenable to making the voices of the subaltern heard. The first step in countering the scourge of socioeconomic inequalities was the recognition of Dalits as a separate category of people in Indian society, distinct from the caste Hindus. Towards this, in his written evidence presented before the Southborough Committee-established to investigate franchise reform in colonial Indiain 1919, Ambedkar (1919; AWS01: 248-250) argued that while Indian society was likely to be divided into Hindus, Muslims, Christians, Parsis, Jews, etc., it was more instructive to classify Hindus into "Touchable" and "Untouchable Hindus". ${ }^{8}$ Untouchability, he further argued, constituted "a definite set of interests which the untouchables alone can speak for" (Ibid:: 256). Thus, not only did Ambedkar agitate for Dalits to be considered a distinctive class of people, but also that the ruling regime must

find the untouchables to represent their grievances which are their interests, and secondly, we must find them in such numbers as will constitute a force sufficient to claim redress (Ibid.: 256).

Ambedkar argued that it was therefore essential that Dalits be awarded self-determination and adequate representation of their own communities. In short, an Ambedkarite ethical manifesto proposes that a system of inequality can only be countered by the oppressed and by them receiving the mantle to do so. Attempts at reform that arise from a system of inequality will only serve to reinforce inequality in a newer form that the subalterns experience, but the reformers cannot understand.

In so doing, Ambedkar followed an "ethical route of persuasion" (Guru 2017, p. 97). In contrast to a confrontational "rushing mode", Ambedkar worked throughout his life in a "reaching mode". Not simply confined to narrow interests of one's own community, he wielded the latter by suspending any form of rash judgements in favour of reflective judgement. Instead of making abstract appeals to some higher ideal, Ambedkar focussed on pointing to the ethical inconsistencies in the dominant group's arguments for a status quo. Guru (2017, p. 98) concludes,

\footnotetext{
${ }^{8}$ Although he classified Dalits within the wider Hindu fold by designating them 'Untouchable Hindus,' this was a position he later revised.
} 
Ambedkar demonstrates the ability to imagine himself as different from his untouchable self. His ethics of persuasion is aimed at making others rise above themselves, the touchable selves. It, thus, plays a normative function to demobilise the self from his/her particular caste/gender location, and mobilises such as an abstracted self to the universal horizon where this self can meet other selves on a universal ground of dignity.

The Dalits of India are not a single cultural group. They possess their own cultural specificities that informed their identities in organic ways. Likewise, the workers of the world who face the yoke of inequality are dispersed in space, culturally distanced, and beyond the shared experience of marginalization do not have any common identity. Ambedkar's unique ability to unify the Dalits of India to fight for representation beyond parochial interests of one's own community presents possibilities for a similar strategically essential coalition of those who fight for greater equality in the capitalist and post-capitalist spaces of the twenty-first century.

\section{Conclusion}

The issue of caste-based discrimination has broken free of its Indian origins, and is now used to analyse other forms of exploitation, indenture, and enslavement (Wilkerson 2020). For scholars examining inequality, the concept of caste and the teachings of Ambedkar provide a promising entry point to formulate potential responses to contemporary societal inequalities, for two reasons. First, the terrain of socioeconomic and representational inequality that Ambedkar encountered in twentieth-century India was characterized by sedimented and institutionally mandated barriers to mobility faced by lower castes. Similar barriers to mobility are currently faced by the working poor in capitalist society, who also tend to be predominantly from demographically underprivileged populations. Real barriers to advancement include the severe restrictions on spatial mobility, denial of access to state-based aid and civil-society initiatives, the normalization of inequitable and unjust systems of compensation, and the constant tweaking of rules (e.g. through lowered taxes for the wealthy, shareholder dividends, and reduction in social services at the lower end of the economic spectrum). To the extent that Ambedkar was able to highlight it and organize around it, he represents a valuable template for organizational theorists, particularly to those interested in inequalities of various kinds that are created, normalized, and reinforced by organizational practices.

The second issue pertains to business ethics as a field of organizational scholarship. Ethics in the field of business has been critiqued as being excessively focussed on following set rules, which denatures the axiological project of any potential for advocacy on behalf of the marginalized (Wray-Bliss 2016). Countering such a perception, Ambedkar's life and works provide a moral imperative for business researchers to find ways out of an institutionalized system that perpetuates, legitimizes, and normalizes the growing inequalities in societies and the miseries they inflict on the poor. An Ambedkarite approach offers the possibility of developing a subaltern-centred perspective, where the sectional interests of dominant groups in organizations are not represented as the interests of the organization as a whole. Instead it calls for states to recognize and endow spaces for the subaltern to represent themselves, as well as contribute towards their reform in all spheres of life through a range of codified, legally enforceable measures.

In this, Ambedkar's scholarship has a potentially significant role to play in the emergent calls to decolonize business and management studies (Dar et al. 2020; Girei 2017; Mir et al. 1999). It is only by calling out centuries of sedimented oppression that we can even begin to address the depredations of global capitalism in poorer nations. Ambedkar's teachings provide an entry point not only to challenge management-colonialism's nexuses but also to reverse historical injustices that the subalterns have been subjected to for millennia. Ambedkar's comprehensive representational politics seeks to overturn the historical oppression faced by Dalit-Bahujan masses within organizations and without. Moreover, even as racial inequalities are rightly subjected to scrutiny in response to decolonizing management, it is imperative that we do the same for caste-based inequalities (our focus, here) as well as demographic inequalities of other kind (e.g. clan, indigeneity, class, ethnicity).

The first order of business, then, for the principled researcher and organizational activist is to reframe the debate, and find ways in which the subaltern subject can be re-enfranchised. Paraphrasing the post-colonial theorist Steven Hahn (2010, p. 189), "to ask if [the subaltern] could 'enfranchise' themselves should lead not to an easy answer but to new interrogations of the worlds of politics and the relations of the many participants". We argue here that Ambedkar's perspective can be deployed as a starting point to contest the position that rising inequalities are an inevitable consequence of industrial growth (Kuznets 1955). Such a discussion can be productive if we focus on representation as a strategy for the organizational theorist working off Ambedkar's position and advocating on behalf of the subaltern.

Finally, Ambedkar not only offers scholars a way to frame the debate, but exemplifies the way to do it through his "ethics of persuasion" (Guru 2017). He offered a subaltern perspective in his writings and speeches, and lived it in action by serving as an example of a struggle for equality and an advocate for the oppressed. His writings 
were plain, simple, and direct yet with great substance and novelty. Beyond scholarship, he was an activist who actively petitioned, argued, goaded, and pressured the elite to achieve reform. On the other hand, he pointed to the inhumanity of the systems of inequality, educated the oppressed, and organized them for collective action. In other words, his commandment of educate, agitate, organize is an appropriate philosophy for scholars of ethics, i.e. to not only educate society about ethics, but agitate its collective mind through such education, and organize it for reform.

Open Access This article is licensed under a Creative Commons Attribution 4.0 International License, which permits use, sharing, adaptation, distribution and reproduction in any medium or format, as long as you give appropriate credit to the original author(s) and the source, provide a link to the Creative Commons licence, and indicate if changes were made. The images or other third party material in this article are included in the article's Creative Commons licence, unless indicated otherwise in a credit line to the material. If material is not included in the article's Creative Commons licence and your intended use is not permitted by statutory regulation or exceeds the permitted use, you will need to obtain permission directly from the copyright holder. To view a copy of this licence, visit http://creativecommons.org/licenses/by/4.0/.

\section{References}

Ajit, D., Donker, H., \& Saxena, R. (2012). Corporate boards in India: Blocked by caste? Economic and Political Weekly, 47(32), 39-43.

Akerlof, G. (1976). The economics of caste and of rat race and other woeful tales. Quarterly Journal of Economics, 90(4), 599-617.

Ali, S. (2020). The laws of Manu and what they would mean for the citizens of the Hindu Rashtra. The Wire. Novermber 10. Retrieved from on January 15. https://thewire.in/rights/manusmriti-hindu -rashtra-rss

Alvaredo, F., Chancel, L., Piketty, T., Saez, E., \& Zucman, G. (2017). Global inequality dynamics: New findings from WID.world. Working Paper 23119. Cambridge, MA: National Bureau of Economic Research.

Ambedkar, B. R. (nd). The triumph of Brahminism. Unpublished manuscript [AWS volume 03].

Ambedkar, B. R. (nd). Untouchables or the children of India's ghetto. Unpublished manuscript [AWS volume 05].

Ambedkar, B. R. (1916). Castes in India: Their mechanism, genesis, and development. Paper read at the Columbia University, New York [AWS volume 1].

Ambedkar, B. R. (1919). Evidence before the Southborough Committee: Written statement. Evidence submitted and examined in January, 1919 [AWS volume 01].

Ambedkar, B. R. (1928). Dr. Ambedkar with the Simon Commission (Indian Statutory Commission. Report containing views and recommendations regarding the constitution of the Bombay Presidency [AWS volume 2, pp. 315-489].

Ambedkar, B. R. (1936). Philosophy of Hinduism. [AWS 03].

Ambedkar, B. R. (1942). Grievances of the Scheduled Castes. Memorandum submitted to the Governor General of India [AWS volume $10]$.
Ambedkar, B. R. (1944). Annihilation of caste, with a reply to Mahatma Gandhi. [AWS volume 1].

Ambedkar, B. R. (1945a). States and minorities: What are their rights and how to secure them in the Constitution of Free India. [AWS volume 1].

Ambedkar, B. R. (1945b). What Congress and Gandhi have done to the untouchables? [AWS volume 9].

Ambedkar, B. R. (1946). Scheduled castes want political safeguards. [AWS volume 17(1)].

Ambedkar, B. R. (1948). The untouchables: Who were they and why they became untouchables? New Delhi: Amrit Book Co. [AWS volume 07]

Ambedkar, B. R. (1951). Election manifesto of the Scheduled Castes Federation. [AWS volume 17(1)].

Ambedkar, B. R. (1990). Waiting for a visa. Manuscript as part of People's Education Society, Mumbai collections. [AWS volume 12].

Ambedkar, B. R. (2014). Annihilation of caste: The annotated (critical). New Delhi: Navayana.

Amis, J. M., Mair, J., \& Munir, K. A. (2020). The organizational reproduction of inequality. Academy of Management Annals, 14(1), $1-36$.

Amis, J. M., Munir, K. A., Lawrence, T. B., Hirsch, P., \& McGahan, A. (2018). Inequality, institutions and organizations. Organization Studies, 39(9), 1131-1152.

Banerjee, A., Bertrand, M., Datta, S., \& Mullainathan, S. (2009). Labor market discrimination in Delhi: Evidence from a field experiment. Journal of Comparative Economics, 37(1), 14-27.

Bapuji, H., \& Chrispal, S. (2020). Understanding economic inequality through the lens of caste. Journal of Business Ethics, 162(3), 533-551.

Bapuji, H., Ertug, G., \& Shaw, J. D. (2020). Organizations and societal economic inequality: A review and way forward. Academy of Management Annals, 14(1), 60-91.

Bapuji, H., Patel, C., Ertug, C., \& Allen, D. (2020). Corona crisis and inequality: Why management research needs a societal turn. Journal of Management. https://doi.org/10.1177/0149206320925881.

Beal, B. D., \& Astakhova, M. (2017). Management and income inequality: A review and conceptual framework. Journal of Business Ethics, 142(1), 1-23.

Brecher, M. (1959). Nehru: A political biography. Oxford: Oxford University Press.

Chandavarkar, R. (1994). The origins of industrial capitalism in India: Business strategies and the working classes in Bombay, 1900 1940. Cambridge: Cambridge University Press.

Chatterjee, P. (1993). The nation and its fragments: Colonial and postcolonial histories. Princeton: Princeton University Press.

Chrispal, S., Bapuji, H., \& Zietsma, C. (2020). Caste and organization studies: Our silence makes us complicit. Organization Studies. https://doi.org/10.1177/0170840620964038.

Combs, G. M., \& Nadkarni, S. (2005). The tale of two cultures: Attitudes towards affirmative action in the United States and India. Journal of World Business, 40(2), 158-171.

Dar, S., Liu, H., Martinez Dy, A., \& Brewis, D. N. (2020). The business school is racist: Act up! Organization. https://doi. org/10.1177/1350508420928521.

Dayanandan, A., Donker, H., \& Nofsinger, J. (2019). The role of caste for board membership, CEO, and interlocking. Pacific-Basin Finance Journal, 54, 29-41.

Di Lorenzo, F., \& Scarlata, M. (2019). Social enterprises, venture philanthropy and the alleviation of income inequality. Journal of Business Ethics, 159(2), 307-323.

Gautier, A., \& Pache, A. C. (2015). Research on corporate philanthropy: A review and assessment. Journal of Business Ethics, 126(3), 343-369. 
Girei, E. (2017). Decolonizing management knowledge: A reflexive journey as practitioner and researcher in Uganda. Management Learning, 48(4), 453-470.

Gramsci, A. (1971). Selections from the prison notebooks of Antonio Gramsci. Edited and translated by Quentin Hoare and Geoffrey Nowell Smith. New York: International Publishers.

Guha, R. (1988). Preface. In R. Guha \& G. C. Spivak (Eds.), Selected subaltern studies (pp. 35-36). Oxford: Oxford University Press.

Guru, G. (2017). Ethics in Ambedkar's critique of Gandhi. Economic \& Political Weekly, 52(15), 95-100.

Hahn, S. (2010). Could slaves enfranchise themselves? Rumours, narratives, and arenas of politics in the American South. In G. Pandey (Ed.), Subaltern citizens and their histories: Investigations from India and the USA (pp. 178-192), Abingdon: Routledge.

Haq, R. (2012). The managing diversity mindset in public versus private organizations in India. The International Journal of Human Resource Management, 23(5), 892-914.

Haq, R., Klarsfeld, A., Kornau, A., \& Ngunjiri, F. W. (2020). Diversity in India: Addressing caste, disability and gender. Equality, Diversity and Inclusion: An International Journal, 39(6), 585-596.

Heath, J., Moriarty, J., \& Norman, W. (2010). Business ethics and (or as) political philosophy. Business Ethics Quarterly, 20(3), 427-452.

Ilaiah-Shepherd, K. (2018). Where are the Shudras? Why the Shudras are lost in today's India. The Caravan. September 30. https://carav anmagazine.in/caste/why-the-shudras-are-lost-in-today-india

Jagannathan, S., Bawa, A., \& Rai, R. (2020). Narrative worlds of frugal consumers: Unmasking romanticized spirituality to reveal responsibilization and de-politicization. Journal of Business Ethics, 161(1), 149-168.

Joshi, S., \& Malghan, D. (2017). Faculty diversity at the Indian Institutes of Management: A preliminary snapshot. Economic and Political Weekly, 52(13), 12-14.

Karunakaran, V. (2016). The Dalit-Bahujan guide to understanding caste in Hindu scripture. Medium.com. July 13. Retrieved June 11,2020, from https://medium.com/@Bahujan_Power/the-dalit -bahujan-guide-to-understanding-caste-in-hindu-scripture-417db 027 fce 6

Keer, D. (1990). Dr Ambedkar life and mission. Bombay: Popular Prakashan.

Khare, A., \& Varman, R. (2016). Kafkaesque institutions at the base of the pyramid. Journal of Marketing Management, 32(17-18), $1619-1646$.

Kudaisya, M. (2006). The life and times of G. D. Birla. New Delhi: Oxford University Press.

Kumar, A. (forthcoming). Philanthropy and the development of modern India: In the name of nation. Oxford: Oxford University Press.

Kumar, A. (2015). Radical equality: Ambedkar, Gandhi, and the risk of democracy. Stanford: Stanford University Press.

Kuznets, S. (1955). Economic growth and income inequality. The American Economic Review, 45(1), 1-28.

Mahalingam, R. (2003). Essentialism, culture, and power: Representations of social class. Journal of Social Issues, 59(4), 733-749.

Mahalingam, R., Jagannathan, S., \& Selvaraj, P. (2019). Decasticization, dignity, and 'dirty work' at the intersections of caste, memory, and disaster. Business Ethics Quarterly, 29(2), 213-239.

Metcalf, B. D., \& Metcalf, T. R. (2006). A concise history of modern India. Cambridge: Cambridge University Press.

Mir, R., Calas, M., \& Smircich, L. (1999). Global technoscapes and silent voices: Challenges to theorizing global cooperation. In D. Cooperrider \& J. Dutton (Eds.), Organizational dimensions of global change (pp. 270-290). London: Sage Publications.

Morris, D. M. (1960). Caste and the evolution of the industrial workforce in India. Proceedings of the American Philosophical Society, 104(2), 124-133.
Morris, D. M. (1965). The emergence of an industrial labour force in India: A study of the Bombay cotton mills, 1854-1947. Berkeley: University of California Press.

Mukherjee, A. P. (2009). BR Ambedkar, John Dewey, and the meaning of democracy. New Literary History, 40(2), 345-370.

Nanda, B. R. (1990). In Gandhi's footsteps: The life and times of Jamnalal Bajaj. New Delhi: Oxford University Press.

Noronha, E. (2019). Caste and workplace bullying: A persistent and pervasive phenomenon. In P. D'Cruz, E. Noronha, C. Caponecchia, J. Escartín, D. Salin, \& M. Tuckey (Eds.), Dignity and inclusion at work handbooks of workplace bullying, emotional abuse and harassment (Vol. 3). Singapore: Springer.

Noronha, E., \& Sharma, R. N. (2002). Indian industry and ethnicity: A study of two organizations in Mumbai. Global Business Review, $3(1), 153-170$.

Omvedt, G. (2008). Ambedkar: Towards an enlightened India. New Delhi: Penguin.

Palshikar, S. (1996). Gandhi-Ambedkar interface. Economic and Political Weekly, 31(31), 2070-2072.

Pandey, J., \& Varkkey, B. (2020). Impact of religion-based caste system on the dynamics of Indian Trade Unions: Evidence from two state-owned organizations in North India. Business \& Society, 59(5), 995-1034.

Prasad, A., O’Brien, L. T., Smith, E., \& Sockbeson, C. (2020). Caste at work: study of factors influencing attitudes toward affirmative action in India. Equality, Diversity and Inclusion, 39(6), 597-616.

Rauf, A. A., \& Prasad, A. (2020). Temporal spaces of egalitarianism: The ethical negation of economic inequality in an ephemeral religious organization. Journal of Business Ethics, 162(3), 699-718.

Roy, A. (2017). The doctor and the saint: Caste, race, and Annihilation of Caste. Chicago: Haymarket Books.

Samel, S. H. (1999). Mahad Chawadar Tank Satyagraha of 1927: Beginning of Dalit Liberation under B. R. Ambedkar. Proceedings of the Indian History Congress, 60, 722-728.

Sangharakshita. (1986). Ambedkar and Buddhism. Glasgow: Windhorse Publications.

Spivak, G. C. (1988). Can the subaltern speak? In C. Nelson \& L. Grossberg (Eds.), Marxism and the interpretation of culture (pp. 271-313). Basingstoke: Macmillan.

Sprong, S., Jetten, J., Wang, Z., Peters, K., Mols, F., Verkuyten, M., et al. (2019). "Our country needs a strong leader right now": Economic inequality enhances the wish for a strong leader. Psychological Science. https://doi.org/10.1177/0956797619875472.

Srinivas, N. (2013). Could a subaltern manage? Identity work and habitus in a colonial workplace. Organization Studies, 34(11), $1655-1674$.

Teltumbde, A. (2017). Dalits: Past, present and future. Abingdon: Routledge.

Thorat, S. (1998). Ambedkar's role in economic planning and water policy. Delhi: Shipra Publications.

Thorat, S., \& Newman, K. S. (2007). Caste and economic discrimination: Causes, consequences, and remedies. Economic and Political Weekly, 42(41), 4121-4124.

Vajpeyi, A. (2012). Righteous republic: The political foundations of modern India. Cambridge: Harvard University Press.

Varman, R., \& Chakrabarti, M. (2004). Contradictions of democracy in a workers' cooperative. Organization Studies, 25(2), 183-208.

Varman, R., \& Vijay, D. (2018). Dispossessing vulnerable consumers: Derealization, desubjectification, and violence. Marketing Theory, 18(3), 307-326.

Wa Thiong'o, N. (1992). Decolonising the mind: The politics of language in African literature. Nairobi: East African Publishers.

Wilkerson, I. (2020). Caste: The origin of our discontents. New York: Random House.

Wilkinson, R., \& Pickett, K. (2009). The spirit level: Why equality is better for everyone. London: Penguin. 
Wray-Bliss, E. (2016). Ethical philosophy, organization studies and good suspicions. In R. Mir, H. Willmott, \& M. Greenwood (Eds.) The Routledge companion to philosophy in organization studies (pp. 51-65). Abingdon: Routledge.

Zelliot, E.M. (1969). Dr. Ambedkar and the Mahar movement. PhD Thesis. University of Pennsylvania.

Zelliot, E. (1970). Mahar and non-brahman movements in Maharashtra. The Indian Economic \& Social History Review, 7(3), 397-415.
Publisher's Note Springer Nature remains neutral with regard to jurisdictional claims in published maps and institutional affiliations. 